\title{
POLITIK DALAM ISLAM: MAKNA, TUJUAN DAN FALSAFAH (Kajian Atas Konsep Era Klasik)
}

\author{
Burhanuddin Yusuf \\ Dosen Aqidah dan Filsafat Islam \\ Fakultas Ushuluddin, Filsafat dan Politik \\ UIN Alauddin Makassar \\ E-mail: yusuf.burhanuddin@gmail.com
}

\begin{abstract}
Pembicaraan tentang "politik" seperti mata air yang tidak pernah kering. Memang, harus diakui bahwa politik erat kaitannya dengan kekuasaan, sedang kekuasaan itu sendiri adalah salah satu hal yang paling diminati oleh manusia. Agaknya tidak berlebihan jika dikatakan bahwa kajian bidang ini dalam berbagai dimensinya selalu menjadi menarik.

Di antara obyek kajian yang menarik adalah pembicaraan tentang teori-teori politik dari tokoh atau sumber klasik. Ini penting oleh karena dari sana, dapat ditarik benang merah, sekaligus sebagai bahan pertimbangan bagi segala teori dan kegiatan politik era berkembang kini. Tiga tokoh klassik yang berjasa mengemukakan teorinya di bidang kajian ini adalah Plato, Aristoteles dan al-Farabi. Pada prinsipnya, ketiga tokoh tersebut sepaham bahwa negara terbentuk karena faktor kebutuhan dari warga yang hanya bisa dipenuhi lewat kerjasama (dalam negara).
\end{abstract}

Keywords:

Politik Islam, Politik Klasik, Al-Farabi

\section{PENDAHULUAN}

Obyek bahasan yang tidak pernah kering-keringnya adalah tentang "pembahas" itu sendiri, yakni tentang manusia. Manusia disebut makhluk sosial. Ia hidup di tengahtengah komunitasnya, mulai dari kelompok sederhana yang disebut dengan kelurga sampai dengan kelompok terbesar, yakni sebagai umat manusia yang mengisi bumi ini. Manusia eksis dalam berbagai dimensi kehidupan, karena ia berada di tengah-tengah masyarakatnya. Ia berharga, karena dihargai oleh Allah dan juga oleh sesamanya. Sebaliknya, ia hina karena terhina oleh Allah dan juga oleh masyarakatnya.

Makhluk yang bernama manusia ini tidak dapat hidup secara mandiri dalam arti yang sebenarnya. Ia sangat tergantung kepada penciptanya, makhluk lain dan sesamanya manusia. Pendek kata, manusia yang biasa disebut sebagai makhluk Allah terbaik itu, sebenarnya tidak lebih dari makhluk yang memiliki tingkat ketergantungan besar kepada selainnya, dan itulah yang menjadi salah satu cirinya.

Kehidupan bersama dalam jalinan saling bergantung satu dengan yang lainnya itu berisi saling interaksi terhadap dan oleh sesama manusia meliputi kepandaian, moral, kepercayaan, hukum, adat istiadat dan sebagainya, maka terbentuklah budaya atau 
kebudayaan. ${ }^{1}$ Untuk efisiensi kerja dalam upaya mencapai tujuan bersama dan untuk menjaga kelestarian hidup bersama, diperlukan bentuk kerja berjamaah, dan untuk semuanya itu, diperlukan organisasi dengan segala perangkatnya. ${ }^{2}$

Sungguhpun demikian, karena miliunya, manusia suka lupa akan eksistensi kediriannya sebagai makhluk kerjasama. Ia menjadi lupa diri, karena merasa tidak tergantung kepada siapa-siapa dan kepada apa-apa; bahkan ia merasa bahwa orang lainlah yang tergantung kepadanya. Dalam hal ini Kontowijoyo secara tegas membenarkan kenyataan ini, bahkan menunjuk firman Allah dalam QS. Al-Alaq/ 96: 67 sebagai berikut: ${ }^{3}$

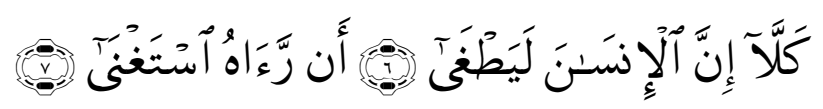

Terjemahnya:

Sekali-kali tidak! Sungguh, manusia itu benar-benar melampaui batas. Apabla melihat sirinya serba cukup. ${ }^{4}$

Di antara jenis penyakit yang biasa menghinggapi manusia adalah penyakit kekuasaan, dalam hal mana pemegang kekuasaan itu menjadi lupa diri dan semenamena dalam mengelola dan mengendalikan kekuasaannya. Ia tidak lagi menghormati tatanan kemasyarakatan, bahkan ia merasa bahwa dirinyalah yang menenetukan dan menciptakan tatanan itu. Memang dalam kenyataan sejarah, kekuasaan itu dapat saja membuat pemegangnya mabuk, menjadi penguasa yang zalim, seperti Fir'aun, namun dapat juga menjadikan pemegangnya menjadi lebih dekat kepada Allah, sesamanya dan bahkan makhluk lainnya, sebagaimana yang ditunjukkan oleh Nabiyulllah Sulaiman, as. dan Daud, as.

Kekuasaan adalah salah satu unsur penting dari kehidupan bermasyarakat, dan ini masuk dalam pembicaraan politik. Memang dalam pengertian umum, politik itu berkaitan dengan pelaksanaan kekuasaan dalam masyarakat atau negara, dan karena masyarakat tidak bisa hidup terlepas dari kelompok masyarakat dengan organisasinya, maka pembicaraan tentang pemegang otoritas kekuasaan itu menjadi penting dan menarik.

Sisi lain dari pembicaraan tentang politik adalah bahwa pengertian dan kegiatan politik itu cukup dinamis, searah dengan dinamisnya perkembangan masyarakat itu sendiri. Sudah barang tentu, pengertian, pendefenisian dan cakupan obyek pembicaraannya akan berubah, berkembang dari satu masa ke masa.

Untuk menjadi bahan bandingan atas apa yang menjadi obyek pembicaraan politik era kekinian, menarik untuk kembali dikaji tentang pemikiran politik tokohtokoh klasik. Hal ini perlu oleh karena kelihatannya, walaupun secara umum, materi dan metode pemikiran mereka sudah boleh disebut sebagai kurang cocok dengan era kini,

\footnotetext{
${ }^{1}$ Hassan Sadili, Sosiologi untuk Masyrakat Indonesia (Jakarta: Rineka Cipta, 1993), h. 47.

${ }^{2}$ Kartini Kartono, Pemimpin dan Kepemimpinan (Jakarta: Raja Grapindo Persada, 2002), h. 1-2.

${ }^{3}$ Kuntowijoyo, Identitas Politik Umat islam (Bandung: Mizan, 1997), h. 24.

${ }^{4}$ Departemen Agama RI., Al-Qur,an dan Terjemahnya (Surabaya: Mekar Sari, 2002), h. 904.
} 
namun untuk segi-segi tertentu lainnya, seperti segi filosofi, tujuan dan lainnya penting untuk kembali dikaji.

Atas dasar pemikiran inilah, maka makalah ini akan mengkaji obyek-obyek dimaksud dari tiga tokoh pemikir politik era klasik, yakni Plato, Aristoteles dan AlFarabi.

\section{PEMBAHASAN}

\section{A. Pengertian Politik.}

Untuk konsumsi umum sehari-hari, ada kesan miring, bahkan negatif pada makna yang terkandung dari kata "politik". Untuk pengertian ini, misalnya, ketika Prof.Dr.H.M. Amin Rais bertanya kepada salah seorang politikus yang juga seorang kiyai tentang alasan kepindahan sang tokoh dari satu partai ke partai lain yang sangat mungkin membuat bingung pengikutnya. Sang tokoh dengan santai menjawab bahwa politik itu kan urusan dunia, sementara urusan dunia itu hanya permainan saja. Bukankah Allah dalam QS. Al-An'am/6:32 Allah swt. berfirman:

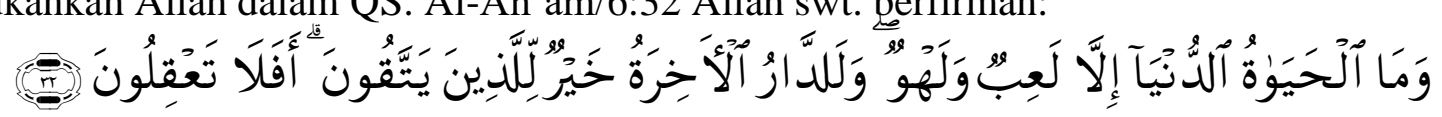

Terjemahnya:

Dan kehidupan dunia ini hanyalah permainan dan senda gurau. Sedangkan negeri akhirat, sungguh lebih baik bagi orang-orang yang bertaqwa. Tidakkah kamu mengerti? ${ }^{5}$

Sementara untuk makna yang berkonotasi negatif, kata politik dipahami sebagai bidang kegiatan yang mengandung unsur-unsur kelicikan, hipokrisi, ambisi buta, penghianatan, penipuan dan sejumlah kata lainnya yang mengandung makna kurang terpuji. ${ }^{6}$ Dari pemahaman seperti inilah maka dapat dipahami, kenapa sebagian orang tua mewanti-wanti putra-putrinya untuk tidak terjun ke dunia politik.

Terlepas dari pemahaman masyarakat umum yang cukup keliru seperti tergambar di atas, ternyata kajian politik adalah salah satu kajian yang cukup menarik. Cukup banyak ahli yang telah mengambil bahagian dalam membahas dan mengembangkannya, baik pemikiran politik secara umum maupun secara khusus, yang dikaitkan dengan konsep ajaran tertentu, seperti agama, budaya dan sebagainya.

Kata atau istilah "politik" dalam bahasa Indonesia terambil dari kata bahasa Inggris, yakni politic, yang secara harfiah bermakna (1) acting or juding wisely; prudent (2) well judged; prudent atau sikap bijaksana atau hati-hati dalam bersikap, dan

\footnotetext{
${ }^{5}$ Departemen Agama RI., Al-Qur,an dan Terjemahnya, h. 176.

${ }^{6}$ M. Amin Rais, Cakrawala Islam, antara Cita dan Fakta (Bandung: Mizan, 1996), h. 23.
} 
melakukan kebijaksanaan atau tindakan bijak. ${ }^{7}$ Kata tersebut juga bermakna The art of government atau tata pemerintahan/seni pemerintahan. ${ }^{8}$

Dalam Kamus Besar Bahasa Indonesia, "politik" diartikan dengan (1) (pengetahuan) yang berkenaan dengan ketatanegaraan atau kenegaraan (seperti sistem pemerintahan dan dasar pemerintahan); (2) Segala urusan dan tindakan (kebijakan, siasat dsb.) mengenai pemerintahan negara atau terhadap negara lain; (3). Cara bertindak (dalam menghadapi dan menangani suatu masalah). ${ }^{9}$

Kata turunan dari kata "politik", seperti "politikus" atau "politisi" berarti orang yang ahli di bidang politik atau ahli ketatanegaan atau orang yang berkecimpung di bidang politik. Kata, "politis" berarti bersifat politik atau bersangkutan dengan politik, dan "politisasi" berarti membuat keadaan (perbuatan, gagasan dan sebagainya) bersifat politis. ${ }^{10}$ Sementara itu, makna dari kata "aspek-aspek politik" yaitu segala sesuatu yang berkaitan dengan urusan pemerintahan, sistem negara, hubungan antara pemerintah dengan rakyat, hubungan antar negara. ${ }^{11}$

Prof.Dr.H.M. Amin Rais menulis bahwa makna yang terkandung pada kata atau istilah "politik" itu meliputi hal-hal yang menyangkut kekuasaaan dan cara penggunaan kekuasaan serta cara dan proses pengelolaan pemerintahan suatu negara. ${ }^{12}$ Sementara itu, dalam pengertian modern, kata "politik" dapat diartikan dengan segala hal yang berkaitan dengan pelaksanaan kekuasaan dalam masyarakat atau negara. ${ }^{13}$ Sejalan dengan itu, Bertrand Russel menulis bahwa hakekat pemerintahan itu adalah penggunaan kekuasaan sesuai dengan hukum untuk menyelamatkan tujuan-tujuan tertentu yang dianggap perlu oleh para pemegang kekuasaan. ${ }^{14}$

Setelah mengkaji sejumlah defenisi tentang politik, Prof.Dr.H.Abd. Muin Salim menyimpulkan pengertian politik kepada dua kecendrungan. Pertama, yang defenisi yang mengaitkannya dengan negara atau urusan pemerintahan, dan yang kedua defenisi yang mengaitkannya dengan masalah otoritas atau kekuasaan. ${ }^{15}$

${ }^{7}$ A.S. Hornby, Oxford Advanced Learner's Dictionary of Current English, (New York: Oxford University Press, 1986), h. 646

${ }^{8}$ Webster's Dictionary, New Revised Edition (Miami, Plorida: PSI Assosiates Inc., 1987), h. 285.

${ }^{9}$ Tim Penyusun kamus Besar Bahasa Indonesia, Kamus Besar Bahasa Indonesia (Jakarta: Balai Pustaka, 2001), h. 886.

${ }^{10}$ Tim Penyusun kamus Besar Bahasa Indonesia, Kamus Besar Bahasa Indonesia, h. 887.

11 Yusuf Qardlawi, Al-Tarbiyat al-Islamiyat wa Madrasat Hasan al-Banna, diterjemahkan ke dalam bahasa In donesia oleh Gazali Mukri dengan judul: Sistem Kaderisasi Ikhwanul Muslimin (Solo: Pustaka Mantiq, 1993), h. 96-97.

${ }^{12}$ M. Amin Rais, Cakrawala Islam, antara Cita dan Fakta, h. 27.

13 A. Rahman Zainuddin, "Ilmu Sejarah, Sosial dan Politik" dalam Taufik Abdullah (eds.), Ensiklopedi Tematis Dunia Islam, Pemikiran dan Peradaban, IV (Jakarta: Ichtiar Baru Van Hoeve, 2002), h. 269.

${ }^{14}$ Bertarnd Russel, Religion and Sicience, diterjemahkan ke dalam bahasa Indonesia oleh Ruslani dengan judul: Perjumpaan Sains - Agama dan Cita-cita Politik (Jakarta: UFUK Press, 2005), h. 271.

15 Abd. Muin Salim, Konsepsi Kekuasaan Politik dalam al-Qur'an (Jakarta: Raja Grapindo Persada, 2002), h. 35. 
Selanjutnya dengan mengutip pandangan Gabriel Almond dan J.S. Coleman, Muin Salim mengemukakan dua fungsi utama politik, yaitu fungsi-fungsi masukan (input punctions) dan fungsi-fungsi keluaran (output punctions), Yang termasuk dalam input punctions meliputi Sosialisasi politik, Rekruitmen politik, artikulasi kepentingan, agregasi kepentingan dan komunikasi politik; sementara yang masuk dalam kategori output punctions adalah pembuatan aturan-aturan, pelaksanaan aturan-aturan dan pengawasan atas pelaksanaan aturan-aturan itu. ${ }^{16}$

Dari beberapa pengertian di atas dapat disimpulkan bahwa kata atau istilah "politik" berkaitan dengan kekuasaan dan penggunaannya, baik itu terbatas pada kelompok masyarakat tertentu dengan skala kecil, maupun dalam skala yang lebih besar dalam suatu negara, bahkan dalam skala internasional dan meliputi bagaimana ia (kekuasaan) itu diperoleh dan bagaimana ia dikelola sesuai dengan aturan-aturan yang telah disepakati dalam masyarakat, negara, atau antar negara di mana ia diterapkan. Singkatnya, politik adalah ketatanegaraan.

Kalau demikian halnya, maka ada dua hal pokok yang terkandung pada kesimpulan di atas tentang makna dari kata atau istilah "politik" tersebut. Pertama, yaitu kekuasaan dan yang kedua adalah cara, teknik atau siasat dalam memperoleh dan melakukan atau menerapkan kekuasaan itu.

Searah dengan dua kandungan kesimpulan di atas, maka penting untuk dikemukakan bahwa dalam kajian Islam, hakikat kekuasaan (الْْْلْدِ) itu adalah milik mutlak dari Sang Khalik, Allah swt. Dia jugalah yang menjadi sumber dari kekuasaan. Ialah yang memberi atau menarik kekuasaan ke atau dari hamba yang Ia kehendaki. Ini sesuai dengan pernyataan dalam QS. Ali Imran/3: $26 \mathrm{sbb}$.:

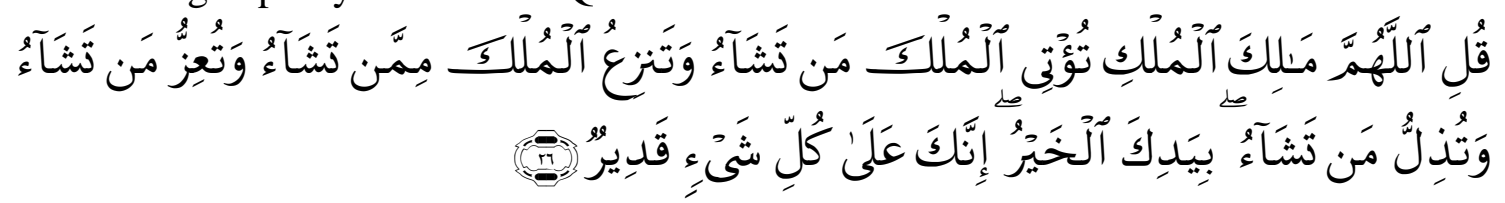

Terjemahnya:

Katakanlah (Muhammad) "Wahai Tuhan Pemilik Kekuasaaan, Engkau berikan kekuasaan kepada siapa pun yang Engkau kehendaki, dan Engkau cabut kekuasaan dari siapa pun yang Engkau kehendaki. Engkau muliakan siapa pun yang Engkau kehendaki, dan Engkau hinakan siapa pun yang Engkau kehendaki. Di tangan Engkaulah segala kebajikan. Sungguh Engkau Maha Kuasa atas segala sesuatu $^{17}$

Dalam hal bagaimana cara, teknik atau siasat dalam memperoleh dan menerapkan kekuasaan, ditemukan sejumlah kaedah atau ketentuan pokok yang mengandung nilai-nilai islami dan bersifat universal yang harus ditegakkan, diantaranya

\footnotetext{
${ }^{16}$ Abd. Muin Salim, Konsepsi Kekuasaan Politik dalam al-Qur'an, h. 41-45.

${ }^{17}$ Departemen Agama RI., Al-Qur'an dan terjemahnya, h. 66.
} 
adalah syura, keadilan, kebebasan/kemerdekaan, persamaan dan pertanggungjawaban di depan rakyat dan Tuhan. ${ }^{18}$

Menurut Ibnu Khaldun, seperti yang distir oleh Prof. Dr.A. Rahman Zainuddin, MA., ${ }^{19}$ kejatuhan suatu bangsa adalah karena para elit hidup bermewah-mewah (mutra fiha) sehingga mencelakakan masyarakatnya. Untuk hidup bermewah-mewah, mereka melakukan korupsi, eksploitasi berlebih-lebihan terhadap sumber-sumbar (alam dan kemanusiaan), maka mereka lalai dari peringatan Allah dalam QS. Al-Isra'/ 17:16 sbb.:

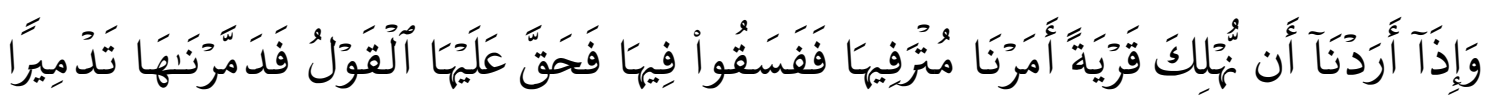

Terjemahnya:

Dan jika Kami hendak membinasakan suatu negeri, maka Kami perintahkan kepada orang yang hidup mewah di negeri itu (agar menaati Allah), tetapi apabila mereka melakukan kedurhakaan di dalam (negeri) itu, maka sepantasnya berlakulah terhadapnya perkataan (hukuman Kami), kemudian kami binasakan (negeri mitu). ${ }^{20}$

dan QS al-Baqarah / 2: 188 sbb.:

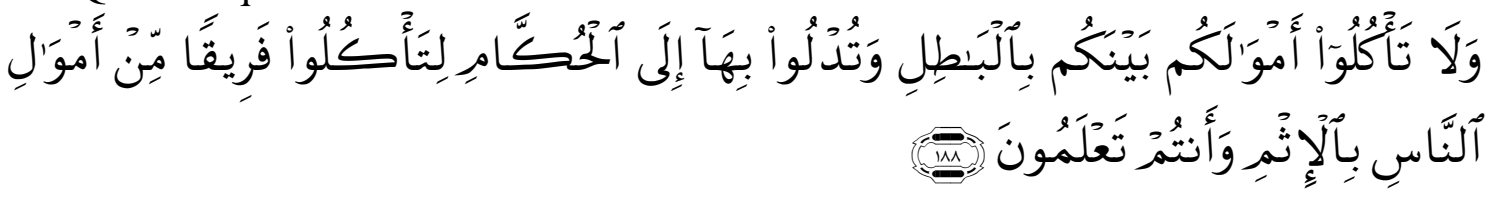

Terjemahnya:

Dan janganlah kamu makan harta di antara kamu dengan jalan yang batil, dan (janganlah) kamu menyuap dengan harta itu kepada para hakim, dengan maksud agar kamu dapat memakan sebagian harta orang orang lain itu dengan jalan dosa, padahal kamu mengetahui. ${ }^{21}$

Dalam ilmu Fiqh, ada satu bagian pokok yang membicarakan tentang masalah perpolitikan, yaitu Fiqh al-Siyasah. Menurut Prof.Dr.H. Ahmad Sukarja, SH., MA., Fiqh Siyasah adalah ilmu tata negara, yang membicarakan tentang seluk-beluk kenegaraan dalam rangka mewujudkan kemaslahatan umat manusia sesuai dengan tuntunan syariat. $^{22}$ Kata atau istilah lain yang semakna dengan itu adalah Siyasah Syar'iyah, al-Ahkam al-Sulthaniyah dan al-Khilafah. Pada prinsipnya, ada empat hal

\footnotetext{
${ }^{18}$ M. Amin Rais, Cakrawala Islam, antara Cita dan Fakta, h. 55.

19 A. Rahman Zainuddin, "Ilmu Sejarah, Sosial dan Politik" dalam Taufik Abdullah (eds.), Ensiklopedi Tematis Dunia Islam, Pemikiran dan Peradaban, IV, h. 269-270.

${ }^{20}$ Departemen Agama RI., Al-Qur'an dan terjemahnya, h. 386.

${ }^{21}$ Departemen Agama RI., Al-Qur'an dan terjemahnya, h. 36.

${ }^{22}$ Ahmad Sukarja, "Fikih siyasah" dalam Taufik Abdullah (eds.), Ensiklopedi Tematis Dunia Islam, Ajaran, II (Jakarta: Ichtiar Baru Van Hoeve, 2002), h. 191
} 
pokok yang dibicarakan dalam Fiqh Siyasah, yaitu (1) Institusi pemerintahan sebagai pengendali aktifitas pemerintahan, (2) masyarakat sebagai pihak yang diatur, (3) kebijaksanaan dan hukum yang menjadi instrumen pengaturan masyarakat dan (4) citacita ideal dan tujuan yang hendak dicapai. ${ }^{23}$

Dari apa yang dikemukakan di atas, ternyata, bidang politik adalah salah satu bidang yang secara serius dibicarakan dalam Islam, dan itu berarti bahwa bidang politik adalah bidang yang cukup penting, sebagaimana pentingnya bidang-bidang lain seperti kalam, fiqh (pada umumhya), tafsir, hadist dan sebagainya.

Kesimpulan di atas akan menjadi lebih kuat, mengingat ada beberapa nash yang secara jelas menyebutkan hal tersebut. Di antaranya adalah firman Allah pada QS. AlNisa/4: 59 sbb.:

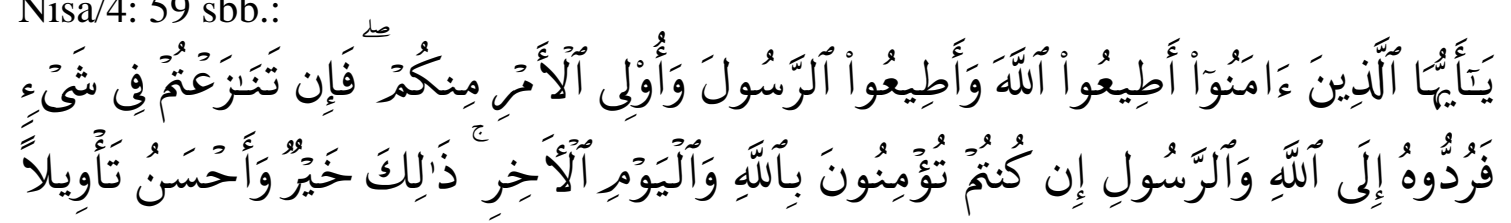

Terjemahnya:

Wahai orang-orang yang beriman! Taatilah Allah dan taatilah Rasul (Muhammad), dan Ulil Amri (pemegang kekuasaan) di antara kamu. Kemudian jika kamu berbeda pendapat tentang sesuatu, maka kembalikanlah kepada Allah (al-Qur'an) dan Rasul (sunnahnya), jika kamu beriman kepada Allah dan hari kemudian. Yang demikian itu lebih utama (bagimu) dan lebih baik akibatnya. ${ }^{24}$

\section{B. Beberapa Teori Politik Klassik.}

Pembicaraan tentang "politik" seperti mata air yang tidak pernah kering. Memang, haru diakui bahwa politik erat kaitannya dengan kekuasaan, sedang kekuasaan itu sendiri adalah salah satu hal yang paling diminati oleh manusia. Agaknya tidak berlebihan jika dikatakan bahwa kajian bidang ini dalam berbagai dimensinya selalu menjadi menarik.

Di antara obyek kajian yang menarik adalah pembicaraan tentang teori-teori politik dari tokoh atau sumber klasik. Ini penting oleh karena dari sana, dapat ditarik benang merah, sekaligus sebagai bahan pertimbangan bagi segala teori dan kegiatan politik era berkembang kini. Tidak heran jika Louis O Kattsoff dalam bukunya elements of Philosophy menempatkan satu bab khusus yang membicarakan panjang lebar tentang sejumlah aspek di bidang politik, dalam batas aspek-aspek politik kekinian, namun

${ }^{23}$ Ahmad Sukarja, "Fikih Siyasah" dalam Taufik Abdullah (eds.), Ensiklopedi Tematis Dunia Islam, Ajaran, II, h. 193.

${ }^{24}$ Departemen Agama RI., Al-Qur'an dan Terjemahnya, h. 114. 
mengurai banyak tentang teori-teori politrik era klasik pada berbagai bagian dari buku tersebut. ${ }^{25}$

Dengan tidak bermaksud menguruangi nilai pemikiran dan kajian dari tokohtokoh klaissik lainnya, pada tulisan ini, penulis membatasi diri pada tiga tokoh saja, yakni dari tiga tokoh filosof terkemuka, masing-masing Plato, Aristoteles dan al-Farabi

1. Plato (427 - $347 \mathrm{sm}$.)

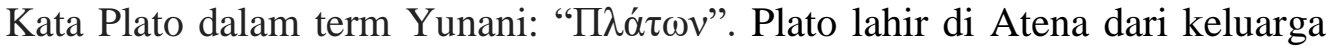
bangsawan pada tahun $427 \mathrm{sm}$. dan meninggal dunia juga di kota yang sama pada tahun $347 \mathrm{sm}$. Plato adalah seorang filsuf, ahli di bidang matematika, penulis philosophical dialogues dan pendiri dari Akademi Platonik di Athena, sekolah tingkat tinggi pertama di dunia barat. Plato menemukan dan mendalami filsafat dari gurunya, Socrates (469 399 sm.) dan sangat setia kepada gurunya itu. Salah satu wujud kesetiaannya itu, ia mengabadikan dialog/pembelaan gurunya di depan pengadilan ketika sang guru dituduh menyesatkan masyarakat dengan ajaran-ajaran filsafatnya. Pembelaannya itu diabadikannya lewat sebuah buku yang berjudul Pembelaan Socrates. ${ }^{26}$

Plato berbeda dari gurunya dalam beberapa segi karya tulis. Kalau sang guru asyik mengajar filsafat lewat dialog-dialog, maka Plato, disamping berdialog, ia cukup produktif mengabadikan pikiran-pikiran dan ide-ide gurunya itu lewat tulisan. Di antara pemikiran filsafat Plato yang menonjol karena banyak dikupas dan dikembangkan oleh para penulis filsafat, adalah ajarannya tentang "Idea" dan tentang "Negara Ideal." Pada intinya, konsep "Idea" Plato membagi alam kepada dua kategori, yakni pertama, "Alam Transenden (noumenal) yang absolut, sempurna, bentuk-bentuk ideal yang tidak berubah di mana yang baik merupakan yang utama yang biasanya ditafsirkan sebagai keindahan dan kebenaran; merupakan sumber dari segala sesuatu yang lain, seperti keadilan,ketentraman, semangat.2. Yang kedua, Alam fenomenal (dunia realitas, dunia tanpak) yang tersusun dari segala sesuatu yang dalam, (mengambil bagian dari) bentuk-bentuk ideal. ${ }^{27}$

\section{Negara Ideal}

Pada dasarnya, Plato menggambarkan negara sebagai diri manusia dalam skala paling mendasar, kemudian melebar sebagai satu keluarga dalam skala yang lebih luas. Cuma perlu digaris bawahi bahwa ketika Plato menyebut "city" atau Negara, adalah masih dalam pemahaman negara dalam ruang lingkup sangat terbatas, dalam hal ini dalam gambaran kota Athena pada saat Plato hidup.

${ }^{25}$ Lihat Louis O Kattsoff, Elements of Philosophy, diterjemahkan ke dalam bahasa Indonesia oleh Drs. Soejono Soemargono dengan judul: Pengantar Filsafat (Yogyakarta: Tiara Wacana, 1986), h. 421-441.

${ }^{26}$ I.R Poedjawijatna, Pembimbing ke Arah Alam Filsafat (Jakarta: Pembangunan, 1978), h. 2729. Lihat juga Mohammad Hatta, Alam Pikiran Yunani (Jakarta: Tintamas, 1982), h. 87-88. Lihat juga https://www.google.co.id/search?q=plato+adalah\&oq=plTO\&aqs=chrome.1.69i57j015.5101j0j7\&sourcei $\underline{\mathrm{d}=\text { chrome\&ie}=\mathrm{UTF}-8}$, diakses pada tanggal 13 Juni 2018.

27 https://www.scribd.com/doc/238359288/Pandangan-Plato-Tentang-Dunia-Ide-Dan-DuniaIndrawi, diakses pada tanggal 13 Juni 2018 
Menurut Plato, Negara Ideal adalah suatu komunitas etikal yang diwujudkan untuk mencapai kebajikan dan kebaikan. Pada hakikatnya, negara ideal itu adalah sebuah keluarga dalam lingkup yang luas "You are all brothers in the city". 28

Selanjutnya Plato menyatakan bahwa negara itu dibentuk oleh manusia yang memiliki begitu banyak keinginan dan kebutuhan dan itu hanya dapat dipenuhi lewat persatuan, kerjasama satu dengan yang lainnya untuk saling dapat menutupi kekurangan, di samping saling menyumbangkan kelebihan.

Dengan demikian, negara adalah suatu sistem pelayanan yang mengharuskan setiap warganya secara bertanggungjawab saling mengisi, saling menukar jasa. Saling memenuhi kebutuhan, saling membangun ${ }^{29}$ dalam rangka mewujudkan tujuannya, yaitu tercapainya kesenangan dan kebahagiaan seluruh warganya. ${ }^{30}$ Dimaksudkan dengan kesenangan di sini bukanlah kesenangan dalam wujud pemuasan hawa nafsu, tapi kesenangan karena beroleh pengetahuan dan mewujudkannya. ${ }^{31}$

Dari paparan di atas dapat disimpulkan bahwa pada Negara Ideal ini, tugas negara adalah mewujudkan kebahagiaan dan kesenangan seluruh warganya, dan dengan demikian maka fungsi negara tiada lain adalah sebagai sarana kesejahteraan.

Bagaimana agar Negara Ideal ini terwujud? Bagi Plato dapat dianalogkan kepada manusia selaku pelaku negara itu sendiri. Dalam hal ini, Plato menyebutkan bahwa manusia itu dari segi kejiwaan dan kemampun dapat dikategorikan atas tiga jenis, yaitu:

Pertama: Golongan Ekonom. Mereka ini adalah rakyat Jelata, yang terdiri atas para petani, pekerja, pedagang, tukang, saudagar. Karena mereka ahli dalam hal menghasilkan sumber-sumber ekonomi, maka tugas mereka adalah membiayai kehidupan negara.

Kedua: Golongan Pembela. Mereka ini memiliki kemampuan bela negara yang handal, karena memiliki keberanian tinggi dan ditopang oleh postur yang meyakinkan. Golongan ini bertugas menjaga negara dari berbagai ancaman, baik dari dalam maupun dari luar.

Ketiga: Golongan Cendekiawan. Mereka ini adalah golongan pilihan dan menempuh masa pendidikan dan latihan yang panjang. Mereka bertugas membuat, melaksanakan dan mengawasi aturan-aturan yang disepakati. Mereka ini adalah kelompok manusia yang hanya memperhatikan kebajikan, kebaikan dan kesejahteraan seluruh warga negara. Mereka ini adalah kelompok penguasa. ${ }^{32}$

Menurut Plato selanjutnya, dalam Negara Ideal, tiap-tiap orang dari tiap-tiap golongan adalah alat semata-mata untuk mencapai kesejahteraan bersama. Golongan ekonom menghasilkan, golongan pelindung menjaga dan dan golongan cendekiawan memerintah.

\footnotetext{
${ }^{28}$ J.H. Rapar, Filsafat Politik Plato (Jakarta: Rajawali, 1993), h.

${ }^{29}$ J.H. Rapar, Filsafat Politik Plato, h. 63.

${ }^{30}$ J.H. Rapar, Filsafat Politik Plato, h. 63

${ }^{31}$ Muhammad Hatta, Alam Pikiran Yunani. (Jakarta: Tintamas, 1982), h. 106.

${ }^{32}$ Mohammad Hatta, Alam Pikiran Yunani, h. 111-112.
} 
Hal menarik dari konsep plato di sini adalah bahwa keadilan terwujud apabila setiap golongan diberi atau mendapat kesempatan seluas-luasnya untuk mengembangkan diri dan fungsinya masing-masing dalam bingkai negara; sebaliknya akan terjadi keruskan bila salah satu atau masing-masing golongan berupaya untuk turut serta melakoni yang bukan menjadi bidangnya.

Selanjutnya, bagi golongan kedua, pembela, agar mereka fokus pada upaya pembelaan negara, segala sesuatu tentang diri dan keperluannya harus sepenuhnya diurus dan dibiayai oleh negara; Wanita/istri, makan-minum, perumahan, anak-anak dan harta benda harus disediakan dan ditanggung oleh negara. Dan karena itu, bagi mereka, tidak ada yang dipikirkan kecuali menjaga dan membela negara, namun mereka tidak memiliki hak pribadi, termasuk istri dan anak-anak. ${ }^{33}$

Kaitan dengan ini, Plato menyebut sejumlah istilah yang bisa dipahami sebagai bentuk-bentuk negara. Yang Petama adalah Aristokrasi yang diperintah oleh kaum Cendikiawan. Pada prinsipnya cedikiawan itu memerintah dengan penuh kebajikan, keadilan, kebijaksanaan dan senantiasa berorientasi pada kepentingan masyarakat secar merata. Negara Ideal adalah yang pemerintahannya model pertama ini. Yang Kedua, yaitu Timokrasi yaitu bilamana penguasa sudah berorientasi pada kepentingan kehormatan dan kemuliaan, yakni bahwa negara yang baik adalah jika negara itu dihormati dan para penguasanya terhormat dan mulia. Yang Ketiga adalah Oligarki. Di sini, pra penguasa tidak merasa cukup bila hanya beroleh kehormatan dan kemuliaan, namun harus beroleh kekayaan yang berlimpah ruah. Di sini sangat rawan penyelewengan kekuasaan dalam bentuk korupsi, kesewenang-wenangan dan penindasan atas rakyat. Yang Keemat yaitu Demokrasi. Bentuk ini biasanya muncul sebagai akibat perlawanan rakyat banyak terhadap pemerintah yang timokrasi dan oligarki. Dapat dipahami bila pada bentuk negara ini, kebebasan individu sangat dihormati. Ujung-ujungnya adalah penggunaan kebebasan yang tak terkendali, maka muncullah kekerasan, ketidak tertiban, anarkis, ketidak sopanan dan kesemuanya ini sangat membahayakan eksistensi negara itu sendiri.

Sebagai ujung dari segalanya, masyarakat kemudian mencari pigur kuat yang dapat menjadi pelindung masyarakat banyak (Protektor People). Cuma saja, pada ujung-ujungnya, karena sangat dihormati, dihargai dan bahkan karena merasa sangat kuat, sang protektor kemudian berubah menjadi penindas dan menyengsarakan rakyat. Inilah bentuk Yang Kelima.

Menurut Plato, hanya bentuk pertamalah (Aristokrasi) yang dapat mewujudkan cita-cita masyarakat menuju Negara Yang Ideal. ${ }^{34}$

Pada akhirnya dapat disimpulkan bahwa Negara Ideal Plato" adalah suatu negara yang dibangun oleh masyarakat untuk memenuhi kebutuhan mereka yang

\footnotetext{
${ }^{33}$ Mohammad Hatta, Alam Pikiran Yunani, h. 111-112.

${ }^{34}$ J.H. Rapar, Filsafat Politik Plato, h. 69-72.
} 
beraneka ragam, yang mustahil dapat terwujud tanpa kerjasama saling memberi dan menerima.

Tujuan dari negara adalah mewujudkan kesenangan dan kebahagiaan setiap warganya, sehingga tugas dari negara adalah untuk mengupayakan terwujudnya kebahagiaan dan kesenangan itu.

2. Aristoteles. (384 - $322 \mathrm{sm}$.)

Aristoteles dianggap sebagai puncak kulminasi dari kejayaan Filsafat Yunani Klassik. Ia dilahirkan di Stageira, Balkan pada tahun $384 \mathrm{sm}$. Dan meninggal dunia di Kalkis pda tahun $322 \mathrm{sm}$. Ia adalah murid dari Plato dan guru dari Alexandros atau Iskandar Agung atau Iskandar Zulqarnain. Pelajaran Filsafat ia peroleh pada Akademia yang didirikan dan diasuh oleh Plato, dan pengetahuan yang diperolehnya itu ia perluas di luar Akademia. Aristoteles sangat taat dan menghargai gurunya, Plato, sungguh pun dalam banyak hal, memiliki perbedaan prinsip dengan pemikiran gurunya. ${ }^{35}$

Sejumlah pemikiran filsafat yang cemerlang karya Aristoteles yang banyak diulas oleh para ahli, antara lain tentang Logika, Jiwa, Fisika, Alam Materi dan tentang Negara.

\section{Negara:}

Sama dengan gurunya, negara bagi Aristoteles adalah lembaga yang harus ada untuk memenuhi salah satu ciri manusia sebagai makhluk zoon politikon, makhluk sosial yang butuh saling isi mengisi, bantu membantu dalam rangka mewujudkan citacita dan tujuan bersama.

Hubungan manusia dengan negara sama dengan hubungan bahagian dengan keseluruhannya. Kewajiban negara adalah mendidik warganya untuk dapat berpendirian tetap, berbudi baik dan pandai berbuat yang terbaik.

Bagi Aristoteles Negara adalah lembaga politik yang paling berdaulat, Negara memiliki kekuasaan tertinggi karena ia adalah lembaga politik dengan tujan yang paling tinggi dan mulia. Tujuan Negara adalah untuk mensejahterahkan seluruh warga negara, bukan individu-individu tertentu. Tujuan lainnya adalah memanusiakan manusia. Jadi Negara yang baik adalah Negara yang sanggup mewujudkan tujuantujuannya itu. Adapun negara yang gagal adalah negara yang tidak mampu mewujudkan cita-citanya itu. ${ }^{36}$

Selanjutnya, Aristoteles menganggap bahwa ilmu politik tidak membentuk manusia, justru memerima manusia apa adanya sebagaimana ia dilahirkan oleh alam. Kaitan dengan ini, maka baginya, bentuk negara yang ideal adalah kombinasi antara Arsitokrasi dengan Demokrasi. Sebabnya adalah Aristokrasi murni sudah tidak ada, dan muncul aristokrasi semu, dimana kursi dan kecakapan dibeli dengan uang, dan ini sangat membahayakan keselamatan negara. Sebaliknya, Demokrasi yang berdiri sendiri

\footnotetext{
${ }^{35}$ Dick Hartoko, Kamus Populer Filsafat (Jakarta: Raja Grapindo Persada, 1995), h. 9. Lihat juga Mohammad Hatta, op. cit., h. 117.

36 http://ilfamutmainah.blogspot.com/2014/04/pemikiran-socrates-plato-da-aristoteles.html., diakses pada tanggal 13 Juni 2018
} 
juga berbahaya, oleh karena kecakapan digantikan oleh jumlah, sementara rakyat kebanyakan mudah tertipu. ${ }^{37}$

Yang menonjol berbeda dengn gurunya, Plato tentang teori kenegaraan ini adalah menyangkut: Pertama, Aristoteles secara tegas menolak gagasan utopis Plato yang meniadakan hak pribadi atas harta, istri dan anak-anak dari golongan pemelihara/pembela. ${ }^{38}$ Kedua, mengenai warga atau unsur tertinggi atau termulia yang harus menjadi barometer dalam negara. Bagi Plato, adalah kaum cendekiawan/filosof, sementara bagi Aristoteles, adalah kelompok menengah. Mereka adalah orang kebanyakan yang berbudi luhur. Mereka hidup dari harta yang diusahakan, dan dari mereka masyarakat dan negara mendapat jaminan ekonomi. ${ }^{39}$

Dari paparan di atas, dapat disimpulkan bahwa teori kenegaraan Plato melalui konsep Negara Idealnya menjadi dasar berpijak bagi pandangan Aristoteles tentang Negara. Dapat dipahami bahwa konsep-konsep negara sang murid banyak kesamaannya dengan sang guru, sungguhpun dalam sejumlah hal berbeda secara prontal. Hal ini antara lain terlihat pada sebab terbentuknya negara. Bagi sang guru, karena faktor kebutuhan, sementara bagi sang murid, karena faktor alami. Selanjutnya, menurut sang guru, bagi golongan penjaga, tidak ada hak pribadi menyangkut segala kebutuhan hidupnya, meliputi istri, harta dan anak-anak, karena seluruhnya disediakan dan dipertanggungjawabkan oleh negara; sedang bagi sang murid, tidak demikian. Selanjutnya, bagi sang guru, kelompok cendekiawan adalah tiang masyarakat, sementara bagi sang murid, justru kelompok menengahlah yang menjadi tiangnya.

3. Al-Farabi. (384 - $322 \mathrm{sm}$.)

Nama lengkapnya adalah Abu Nasr Muhammad ibn Muhammad ibn Tarkhan ibn Uzlag, al-Farabi. Ia lahir di Wajiz, suatu desa dalam lingku Farab (Transoxania) pada tahun $870 \mathrm{M}$ dari keturunan Turki dan wafat di Aleppo pada tahun 950M/339H dalam usia 80 tahun.

Ia dianggap sebagai pembangun pertama Pemikirn Filsafat Islam oleh karena kelengkapan bangunan ajaran dan pemikirannya di bidang filsafat. Ia jugadisebut sebagai "the second teacher" setelah Aristoteles yang digelar sebagai "the first teacher" karena keahlian keduanya di bidang logika. ${ }^{40}$

Di antara buah pemikirannya yang banyak diulas oleh para pemikir di bidang filsafat adalah tentang Logika, Emanasi, Kenabian dan Politik. Sesui dengan topik makalah ini, yang menjadi pokus adalah tentang yng terakhir.

\section{Teori Politik al-Farabi}

\footnotetext{
${ }^{37}$ Mohammad Hatta, Alam Pikiran Yunani,, h. 135-136. Informasi yang sedikit berbeda, dikemukakan oleh Lorens Bagus. Ia menulis bahwa menurut Aristotreles, bentuk pemerintahahan yang terbaik adalah monarki, aristokrasi dan Politeia, sedang bentuk-bentuknya yang merosot adalah tirani, oligarki dan demokrasi. Lihat Lorens Bagus, Kamus Filsafat,(Jakarta: Gramedia, 1996), h. 693.

${ }^{38}$ Lorens Bagus, Kamus Filsafat, h. 82-83.

${ }^{39}$ Mohammad Hatta, Alam Pikiran Yunani, , h. 134-135.

${ }^{40}$ Oemar Amin Hoesin, Filsafat Islam (Jakarta: Bulan Bintang, 1975), h. 87-90.
} 
Majid Fakhri menulis bahwa pemikiran politik al-Farabi mencerminkan hubungan yang akrab antara metafisika dengan ilmu politik, dalam hal mana terlukis pandangan organik manusia dalam hubungannya dengan Tuhan, Sesama manusia dan alam semesta. Dalam teori ini al-Farabi secara nyata melukiskan ilmu etika dan politik sebagai perluasan (highest manipestasion) dari metafisika yang tingkat tertingginya adalah pencapaian ilmu tentang Tuhan. ${ }^{41}$

Bagaimana pun juga, seperti yang ditulis oleh Dick Hartoko, pandangan negara al-Farabi diilhami oleh karya Plato Politeia dan Nomoi. ${ }^{42}$ Karena dalam sejarah filsafat, gelar al-Farabi yang lain dari yang telah disebutkan di atas adalah "Sang Komentator" bagi Plato dan Aristoteles. Sungguhpun harus dicatat bahwa di samping mengulas, Al-Farabi juga membahas dan mengembangkan. Al-Farabi mewarnai seluruh pemikirannya dengan ajaran agama yang dianutnya, yang dalam istilh Majid Fakhri di atas, as embodied in the Islamic system of beliefs (seperti yang diwujudkan dalam sistem kepercayaan dalam agama Islam).

Pemikiran Politik Al-Farabi banyak dituangkan dalam dua karyanya, yakni Ara' ahl al-Madinat al-Fadilah dan Al-Siyasat al-Madaniyyah. Pada kedua karya tersebut, al-Farabi, sebagaimana halnya Plato melukiskan bahwa manusia itu adalah makhluk sosial yang tidak mungkin hidup sendiri-sendiri. Mereka harus hidup rukun, damai, bantu-membantu untuk mewujudkan tujuan hidup bersama, yaitu menggapai kebahagian. Itulah Masyarakat utama (al-Mujtama' al-Kamil) yang menjadi tiang utama bagi terbentuknya negara. Masyarakat Utama ini berisi komponen masyarakat yang bekerja menurut bidang dan keahlian masing-masing, sebagaimana tubuh manusia, yang setiap bagiannya bekerja menurut bidang dan fungsinya masing-masing. ${ }^{43}$

Dalam hal ini, pekerjaan setiap anggota masyarakat akan berbeda-beda, sesuai dengan bidang dan kemampuan masing-masing, namun keselurhannya adalah tertuju pada tujuan yang satu, dalam bingkai kordinasi sang kepala negara, yaitu terjalinnya hubungan harmonis antara manusia dengan Tuhan, dengan sesamanya dan dengan alam sekitarnya, yang sudah barang tentu secara otomatis akan mewujudkan kemakmuran dan kebahagiaan seluruh warga negara dari negara utama itu. ${ }^{44}$

Di sini, terlihat peran sentral yang sangat menentukan dari kepala negara. Memang dalam teori ini, kepala negara disejajarkan dengan "hati" dalam sistem $\mathrm{fa}^{\prime}$ ' tubuh manusia, yang dianggap sebagai organ terpenting dan paling sempurna dalam tubuh manusia. ${ }^{45}$ Alasan lain berkenaan dengan peran sentral hati pada diri manusia

\footnotetext{
${ }^{41}$ Majid Fakhri, A History of Islamc Philosophy (New York: Columbia University Press, 1983), h. 117.

42 Dick Hartoko, Kamus Populer Filsafat, h. 30.

${ }^{43}$ Sirajuddin Zar, Filsafat islam, Filosof dan Filsafatnya (Jakarta: Raja Grapindo Persada, 2002), h. $82-83$.

44 Poerwantana, dkk., Seluk Beluk Filsafat Islam (Bandung: Rosda, 1988), h. 138-139.. Selanjutnya lihat A. Hanafi, Pengantar Filsafat Islam (Jakarta: Bulan Bintang, 1976), h. 140-141. Lihat juga http://jendelabacaku.blogspot.com/2013/10/konsep-madinah-al-fadhilah-al-farabi.html.

${ }^{45}$ Poerwantana, dkk., Seluk Beluk Filsafat Islam, h. 139.
} 
adalah sebagaimana yang dipahami dari Hadist Abu Huraerah dari Rasulullah saw. yang menyebutkan hati manusia sebagai penentu baik-buruknya manusia. ${ }^{46}$

Karena demikian pentingnya peran Kepala Negra dalam teori al-Madinat alFadilah al-Farabi ini, sehingga ia memberi persyaratan yang sangat ketat. Menurut Ibrahim Madzkur, ada dua persyaratan, yakni yang bersifat umum dan khusus. Di antara syarat yang bersifat umum adalah bahwa Kepala Negara itu harus dari keturunan yang baik, memiliki postur tubuh yang prima, memiliki intelektualitas yang cemerlang, cerdas, tangkas, cinta ilmu, jujur, amanah, adil, optimis, besar hati, toleran dan memiliki kemampuan menjauhi kelezatan hidup. Adapun persyartan khusus adalah sang kepala negara harus mampu berhubungan dengan al-aql al-Fa'al yang merupakan sumber ilham dan wahyu. ${ }^{47}$ Di sini dapat dipahami bahwa sesungguhnya al-Farabi dengan teorinya ini menyatakan bahwa yang bisa menjadi kepala negara bagi Negeri Utamanya itu adalah Filosof, karena hanya filosoflah yang memiliki kriteria yang diajukan itu.

Selanjutnya, al-Farabi menyatakan bahwa dalam hal negara tidak diperintah oleh sosok yang memiliki persyaratan di atas, maka boleh jadi negara yang dipimpinnya itu tidak membawa warganya kepada tujuan negra tadi, yakni kemakmuran dan kebahagiaan hidup, justru sebaliknya yng bisa terjadi.

Di antara yang mungkin terjadi adalah terwujudnya al-Madinataat alJahilah yaitu negara yang warganya tidak mengenal dan tidak akan mencapai kebahagiaan hakiki, karena umumnya mereka memburu materi, kehormatan, kemuliaan, kesenangan semu dan untuk itu semua, kaedah-kaedah ilahiah dan etik menjadi hal yang diabaikan. Mungkin juga terwujud Negeri Pembangkang yang warganya banyak melakukan pembangkangan terhadap kaedah-kaedah dan norma-norma dan juga banyak melakukan korup. Selanjutnya mungkin juga terwujud Negeri Fasiq, yang warganya banyak melalkukan kepasikan dalam arti cukup baik mengenal Tuhan dan hukumhukum-Nya, namun tidak mau melakukannya; dan yang terakhir adalah mungkin terwujud Negeri Sesat, yakni negeri yang kepala negaranya, karena merasa serba kuasa, menjadi lupa diri, bahkan menipu warganya, mengaku bahwa dirinya mendapat wahyu. $^{48}$

Dari paparan di atas dapat disimpulkn bahwa secara prinsipil teori Negeri Utama dari al-Farabi adalah pengembangan dari teori Negara Ideal Plato. Ada sejumlah perbedaan, yang bila disimak lebih mendalam itu terjadi karena faktor pengembangan yang dilakukan oleh al-Farabi, setelah teori Plato itu disesuaikan dengan kekinian era al-Farabi dan dipakaikan dengan baju ajaran Islam, agama yang dianutnya.

${ }^{46}$ Hadist Riwayuat Bukhari dan Muslim dari Abu Huraerah, sebagaimana tercantum dalam Hadist 'Arba'in al-Nawawi, tentang Halal dan Haram, Hadist No. 6 pada halaman 9. Sumber informasi: CD Hadistr (Khusus)

${ }^{47}$ Ibrahim Madzkur, Fi al-Falsafat al-Islamiyat, Manhaj wa Ttbiquh, diterjemahkan ke dalam bahasa Indonesi oleh Yudian Wahyudi dan Ahmad Hakim Muzakir dengan judul: Filsafat Islam, Metode dan Penerpan, I (Jakarta: Rajawali Press, 1991), h. 89.

${ }^{48}$ Majid Fakhri, A Short Introduction to Islamic Philosophy, diterjemahkan ke dalam bahasa Indonesia oleh Zainal Am dengan judul: Sejarah Filsafat Islam (Bandung: Mizan, 2001), h. 53. Lihat juga Hanafi, A., Pengantar Filsafat Islam (Jakarta: Bulan Bintang, 1976), h. 142-143. 
Ada dua hal yang menarik dari teori politik ke tiga tokoh di atas (Plato, Aristoteles dan al-Farabi), yaitu pertama, ketiganya menganggap terciptanya negara karena kebutuhan praktis dari warganya; kedua ketiganya menempatkan kebahagiaan sebagai unsur utama dari tujuan negara. Yang berbeda dari ketiganya adalah perumusan dari istilah kebahagiaan itu. Yang ketiga, ketiganya menempatkan moral atau etika sebagai sokoguru utama dan terutama bagi negara ideal yang dicita-citakan.

Kalau berpatokan pada tiga kesesuaian dasar dari tiga tokoh kunci di atas, lalu dihubungakan dengan cita-cita luhur terbentuknya negara kesatuan republic Indonesia, sebagaimana terpateri pada alinea keempat dari pembukaan Undang-undanga Dasar Negara Republik Indonesia tahun 1945, yakni “...untuk melindungi segenap bangsa Indonesia dan seluruh tumpah darah Indonesia, dan untuik memajukan kesejahteraan umum, mencerdaskan kehidupan bangsa, dan ikut melaksanakan ketertiban dunia yang berdasarkan kemerdekaan, perdamaian abadi dan keadilan social ..., ${ }^{49}$ maka sesungguhnya bisa diklaim bahwa dasar pemikiran politik tiga tokoh di atas tidak pernah padam sama sekali. Bahkan jika salah satu dari tiga prinsip di atas dihilangkan berpotensi besar terjadinya kesewenang-wenangan dari unsur tertentu dari negara itu, terutama dari pihak yang memiliki power besar.

\section{KESIMPULAN}

Kata atau istilah politik dalam kosakata bahasa Indonesia terambil dari bahasa Ingris. Kata dan istilah tersebut bermakna segala hal yang berkaitan dengan kekuasaan, terutama meliputi bagaimana ia diperoleh, digunakan dan dipertanggungjawabkan, baik dalam skala terbatas seperti pada keluarga, masyarakat, negara bahkan yang lebih luas lagi adalah antar negara. Istilah politik dalam teori keilmuan dimaknakan dengan ilmu tata negara atau ilmu pemerintahan.

Tiga tokoh klassik yang berjasa mengemukakan teorinya di bidang kajian ini adalah Plato, Aristoteles dan al-Farabi. Pada prinsipnya, ketiga tokoh tersebut sepaham bahwa negara terbentuk karena faktor kebutuhan dari warga yang hanya bisa dipenuhi lewat kerjasama (dalam negara).

Ketiga tokoh di atas sepaham bahwa negara akan berfungsi dengan baik bilamana negara menciptakan kondisi dimana setiap warga memiliki kesempatan seluas-luasnya untuk berkarya menurut bidang, keahlian dan kemampuannya masingmasing dan kepala negara dengan bijaksana memanage warganya dalam prinsip etika yang luhur untuk mencapai kepentingan dan tujuan bersama, yaitu terciptanya kemakmuran dan kebahagiaan bersama. Ketiga tokoh sepaham menempatkan faktor kesempurnaan etika, intelektual dan pisik bagi kepala negara.

Yang lebih menarik dari pandangan politik ke tiga tokoh di atas adalah bahwa bentuk negara yang bersipat "demokrasi" yang di era ini didewa-dewakan, ternyata tidak dianggap sebagai yang terbaik, bahkan ketiganya menganggap demokrasi sebagai

${ }^{49}$ Lembaga Ketahanan RI, Nilai-nilai Kebangsaan yang Bersumber dari UUD NRI Tahun 1945 (Jakarta: Lembaga Ketahanan Nasional Republik Indonesia, 2017), h. viii. 
ancaman bagi eksistensi negara itu sendiri, oleh karena dapat menyebabkan penggunaan kebebasan yang tak terbatas, munculnya anarkis, manipulasi suara, terinjak-injaknya etika/moral dan kepala negara sangat sulit menjalankan tugasnya dengan baik.

\section{DAFTAR PUSTAKA}

Bagus, Lorens, Kamus Filsafat Jakarta: Gramedia, 1996.

Departemen Agama RI., Al-Qur'an dan terjemahnya, Juz 1 - Juz 30. Surabaya: Mekar, 2002.

Fakhri, Majid, A History of Islamc Philosophy. New York: Columbia University Press, 1983.

--------, A Short Introduction to Islamic Philosophy, diterjemahkan ke dalam bahasa Indonesia oleh Zainal Am dengan judul: Sejarah Filsafat Islam. Bandung: Mizan, 2001.

Hanafi, A., Pengantar Filsafat Islam. Jakarta: Bulan Bintang, 1976

Hartoko, Dick, Kamus Populer Filsafat. Jakarta: Raja Grapindo Persada, 1995.

Hatta, Mohammad, Alam Pikiran Yunani. Jakarta: Tintamas, 1982

Hornby, A.S., Oxford Advanced Learner's Dictionary of Current English., New York: Oxford University Press, 1986.

Kartono, Kartini, Pemimpin dan Kepemimpinan. Jakarta: Raja Grapindo Persada, 2002.

Kattsoff, Louis O, Elements of Philosophy, diterjemahkan ke dalam bahasa Indonesia oleh Drs. Soejono Soemargono dengan judul: Pengantar Filsafat. .Yogyakarta: Tiara Wacana, 1986.

Kuntowijoyo, Identitas Politik Umat islam. Bandung: Mizan, 1997.

Lembaga Ketahanan RI, Nilai-nilai Kebangsaan yang Bersumber dari UUD NRI Tahun 1945. (Jakarta: Lembaga Ketahanan Nasional Republik Indonesia, 2017.

Madzkur, Ibrahim, Fi al-Falsafat al-Islamiyat, Manhaj wa Tatbiquh, diterjemahkan ke dalam bahasa Indonesi oleh Yudian Wahyudi dan Ahmad Hakim Muzakir dengan judul: Filsafat Islam, Metode dan Penerpan. I Jakarta: Rajawali Press, 1991.

Poedjawijatna, I.R, Pembimbing ke Arah Alam Filsafat. Jakarta: Pembangunan, 1978.

Poerwantana, A Ahmadi dan M.A. Rosali, Seluk Beluk Filsafat Islam. Bandung: Rosda, 1988.

Qardlawi, Yusuf, Al-Tarbiyat al-Islamiyat wa Madrasat Hasan al-Banna, diterjemahkan ke dalam bahasa In donesia oleh Gazali Mukri dengan judul: Sistem Kaderisasi Ikhwanul Muslimin. Solo: Pustaka Mantiq, 1993.

Rais, M. Amin, Cakrawala Islam, antara Cita dan Fakta. Bandung: Mizan, 1996.

Rapar, J.H., Filsafat Politik Plato. Jakarta: Rajawali, 1993. 
Russel, Bertarnd, Religion and Sicience, diterjemahkan ke dalam bahasa Indonesia oleh Ruslani dengan judul: Perjumpaan Sains - Agama dan Cita-cita Politik. Jakarta: UFUK Press, 2005.

Sadili, Hassan, Sosiologi untuk Masyrakat Indonesia. Jakarta: Rineka Cipta, 1993.

Salim, Abd. Muin, Konsepsi Kekuasaan Politik dalam al-Qur'an (Jakarta: Raja Grapindo Persada, 2002.

Sukarja, Ahmad, "Fikih Siyasah" dalam Taufik Abdullah (eds.), Ensiklopedi Tematis Dunia Islam, Ajaran, II. Jakarta: Ichtiar Baru Van Hoeve, 2002.

Tim Penyusun kamus Besar Bahasa Indonesia, Kamus Besar Bahasa Indonesia. Jakarta: Balai Pustaka, 2001.

Webster's Dictionary, New Revised Edition. Miami, Plorida: PSI Assosiates Inc., 1987.

Zainuddin, A. Rahman, "Ilmu Sejarah, Sosial dan Politik" dalam Taufik Abdullah (eds.), Ensiklopedi Tematis Dunia Islam, Pemikiran dan Peradaban, IV. Jakarta: Ichtiar Baru Van Hoeve, 2002.

Zar, Sirajuddin, Filsafat Islam, Filosof dan Filsafatnya. Jakarta: Raja Grapindo Persada, 2002.

Lembaga Ketahanan RI, Nilai-nilai Kebangsaan yang Bersumber dari UUD NRI Tahun 1945.(Jakarta: Lembaga Ketahanan Nasional Republik Indonesia, 2017.

https://www.scribd.com/doc/238359288/Pandangan-Plato-Tentang-Dunia-Ide-DanDunia-Indrawi

https://www.google.co.id/search?q=plato+adalah\&oq=plTO\&aqs=chrome.1.69i57j015.5 101 j0j7\&sourceid $=$ chrome \&ie $=U \mathrm{UTF}-8$,

http://ilfamutmainah.blogspot.com/2014/04/pemikiran-socrates-plato-da-aristoteles.html http://jendelabacaku.bl ogspot.com/2013/10/konsep-madinah-al-fadhilah-al-farabi.html 